\title{
ORGANIZATIONAL CULTURE AND TQM IMPLEMENTATION IN CONSTRUCTION FIRMS IN SINGAPORE
}

\author{
Abstract \\ The adoption and implementation of Total Quality Management (TQM) are \\ related to a company's culture. The relationship between cultural orientation and \\ the implementation of TQM practices among certified Singapore contractors is \\ investigated from an organizational culture perspective. The Competing Values \\ Framework was used to assess organizational culture and eight TQM elements \\ were identified to gauge the implementation of TQM practices among contractors. \\ A survey questionnaire was administered. Four organizational culture types have \\ been identified from the survey findings. These are strong comprehensive, clan- \\ driven, hierarchy-driven, and weak comprehensive culture. Firms with strong \\ comprehensive culture implement highly the TQM elements of top management \\ leadership, people, process, customer, and supplier management. Firms with clan- \\ driven culture implement highly the element of process management while firms \\ with hierarchy-driven and weak comprehensive culture implement lowly to \\ moderately all elements. A cultural-based TQM implementation strategy is \\ proposed.
}

Keyword: competing values framework, contractor, organizational culture, total quality management. 


\section{INTRODUCTION}

Compelling reasons exist as to why the study of Total Quality Management's (TQM) implementation in organizations warrants the study of organizational culture of these organizations. The concerns stem from the nature of TQM as a management philosophy (Roney, 1997) and its practical orientation towards the management of organization. The implementation of TQM is likely to be manifested in an organization's practices. If we consider organizational culture consists broadly of practices and basic values (Hofstede, 2001; Schein, 1985), there is then a natural relationship between TQM and organizational culture.

Implementing TQM requires the understanding of organizational culture and changing of its underlying values so that quality becomes a state of mind of organizational members. This proposition has been made in the manufacturing and service industry (see for example Sinclair and Collins, 1994; Kekäle and Kekäle, 1995; McNabb and Sepic, 1995; Sousa-Poza et al, 2001; and others). Similar exhortation has been echoed from the construction fraternity (see for example Federle and Chase, 1993; Demski, 1993; Low and Teo, 2004; and others). In this respect, Shammas-Toma et al (1998) have stressed the need of changing organizational culture so that attitudes and expectations within organizations can be in line with TQM's philosophy. In other words, an organizational culture built around TQM must be present so that a foundation of quality can be prevalent (Love and Li, 2000).

Hence, a need to understand the relationship between organizational culture and the implementation of TQM practices is essential. A useful starting point is to study the effect of organizational culture on TQM implementation. We have 
conducted an empirical study to verify this effect among Singaporean construction companies. The study investigates how organizational culture at the construction firm level is related to the implementation of TQM practices in that firm. The organization cultural profiles of local contractors were first explored. These profiles were then linked to the implementation of TQM practices in those firms.

\section{LITERATURE REVIEW}

\section{Organizational culture and TQM practices}

The implementation of TQM practices and organizational culture is mutually dependent. Organizational culture "constrains" the way TQM practices are implemented in organizations. This constraining perspective of organizational culture on TQM practices is based on the congruence and selection arguments of contingency theory (Yeung et al, 1991).

Adopting the perspective of system theory, Nadler and Tushman (1980) considered organizations to consist of subparts or components which must be consistently structured and managed for organizations to be effective. Organizational subparts must be in a state of congruence. The components of formal organizational arrangements that comprise of structure, processes, methods, and procedures i.e. the organizational practices, are required to be explicitly and formally developed to be in line with organizational strategy (Nadler and Tushman, 1980). Practices form part of organizational culture. As organizational culture dictates the way an organization responds to environmental stimuli (in the form of strategy) (Schein, 1985), the congruence argument implies that TQM practices are the manifestations of organizational culture. 
In relation to the concept of congruence, Van de Ven and Drazin (1985) have articulated the concept of "fit” as adherence to a linear relationship between context and structure. "Fit” implies that the design of an organization must adapt to the characteristics of its context for survival and/or effectiveness (Van de Ven and Drazin, 1985). The design of an organization includes the structure and processes (i.e. practices) of the organization. Organizations must select and adapt the structural patterns and suitable practices that match their particular circumstances while simultaneously maintain internal consistency (Van de Ven and Drazin, 1985). In the selection argument, fit is the result of an evolutionary process of adaptation (Drazin and Van de Ven, 1985). Consequently, only those TQM practices that are effective will be retained over time. Both arguments, i.e. the requirements for "fit" and "congruence" have implied that organizational culture constrains on the choice of TQM practices. The cultural constraint argument advocates that as organizational culture becomes entrenched, the organization selects TQM practices that are consistent with its existing culture (see, for example, Cameron and Quinn’s (1998), and Kekäle’s (1999) works linking organizational culture and quality management practices).

\section{Organizational culture}

Adopting the conception of organizational culture propounded by Cameron and Quinn (1998), organizational culture refers to "the taken-for-granted values, underlying assumptions, expectations, collective memories, and definitions present in an organization, ... it reflects the prevailing ideology people carry inside their heads, it conveys a sense of identity to employees, provide unwritten and, often, unspoken guidelines for how to get along in the organization, and 
enhances the stability of the social system that they experience.” (Cameron and Quinn, 1998: 14) Organizational culture thus conceived has many manifestations. These manifestations are likely to be associated with the organizational members' value orientations conditioning and conditioned by the organizational culture. While the shared cognitive assumptions of organizational members are difficult to measure, cultural values manifestations of beliefs and artifacts can be systematically assessed (Yeung et al, 1991). With the instrument developed by Cameron and Quinn (1998) and their colleagues, the value orientations of cultural members can be extracted and represented in cultural profiles. These cultural profiles are ideal types that can be used to characterize the organizational culture. Four ideal types have been identified: hierarchy, clan, adhocracy, and market (Cameron and Quinn, 1998). The main characteristics of the ideal types are given in Table 1.

Although there are four distinctive cultural categories, in reality, organizations are unlikely to reflect only one cultural type. To be effective, the adoption of some elements of each of the four cultural ideal types is necessary (Zammuto and Krakower, 1991; Cameron and Quinn, 1998).

\section{Total quality management domains}

The synthesis of the philosophy, principles, and interventions of the TQM proponents in both construction- and non-construction-based studies has allowed us to identify eight possible domains for the TQM framework. (Crosby, 1979; Juran and Gryna, 1980; Feigenbaum, 1983; Ishikawa, 1985; Deming, 1986; Saraph et al, 1989; Burati et al, 1992; Chase, 1993; Anderson et al, 1994; Dean and Bowen, 1994; Flynn et al, 1994; Spencer, 1994; Hackman and Wageman, 
1995; Ahire et al, 1996; Black and Porter, 1996 etc.) These domains are top management leadership, customer management, people management, supplier management, quality information management, process management, learning, and continual improvement.

The TQM philosophy of satisfying customer needs and organizational survival provide initial impetus for the management of an organization to establish a production system. Top management's support and leadership for quality play the crucial role in ensuring the development and success of quality management (Flynn et al, 1994). The promotion of cooperative spirit within the organization facilitates the implementation of process management, willingness, and ability of organizational members to learn. These lead to continuous improvement of the processes and product/services (Anderson et al, 1994).

The organizational system of the TQM framework comprises of customer, the organizational member, supplier, and quality information management. These activities are implemented along with process management to support continuous improvement initiatives to enhance the production capability. This engenders the satisfaction of customer and the provision of feedback into the system. These two outcomes, in turn, generate sales revenues and system performance information back to the organization and continue into the next cycle of production and improvement (Flynn et al, 1994). In short, the behavioral and methodological aspects of an organization's management systems at the operational level are required for the successful implementation of TQM practices. It is the synergistic implementation of the integral whole that ensures quality improvement in an endless manner (Anderson et al, 1994). 


\section{RESEARCH HYPOTHESES}

The research hypotheses stem from the proposition that organizational culture affects TQM implementation. Certain cultural traits can be associated with certain type of TQM practices. TQM practices are taken as a function of organizational culture. Two main hypotheses can be formulated with the variables.

The first hypothesis $\mathrm{H} 1$ reads:

H1: Organizational culture is significantly related to TQM practices such that TQM practices vary with different organizational cultural orientation. This hypothesis is premised on the constraining perspective in that organizational culture constrains TQM implementation in organizations (Yeung et al, 1991). Both the congruence and selection arguments under the perspective envision that only those TQM practices congruent with the organizational culture are retained over time. Additionally, due to path dependency (Chiles and Choi, 2000) of organizations, TQM practices are expected to vary with different organizational culture. Consequently, it can be further stated from H1 that TQM practices of organizations with different dominant cultural types are significantly different, and that these TQM practices are differentially emphasized.

The second hypothesis $\mathrm{H} 2$ reads:

H2: Organizations at the high level of TQM implementation will demonstrate similar cultural characteristics.

In this conception, TQM values (Detert et al, 2000) are aligned with organizational values. The TQM imperatives that are consistent with cultural values of the organizations are likely to induce support for the underpinnings of 
such cultural values (after Mathews et al, 2001). TQM and culture are seen as mutually reinforcing.

\section{RESEARCH METHOD}

\section{Research design}

The study is descriptive and exploratory in nature; descriptive in the reporting of the phenomena (e.g. organization cultural profiles, TQM practices) and exploratory in the determination of the organizational cultures and their relationships with TQM practices. In addition, to capture the main characteristics of the population, there is a need to cover a wide range of phenomena with a more accessible observation at a less abstract level of organizational phenomena. Less abstract phenomena are more accessible to standardized assessment (Rousseau, 1990). Standardized assessment allows objectivity on the interpretation of the data gathered and potential generalization of the results from a sample to the wider population (Martin 2002). These considerations, together with the economy of the design and the rapid turnaround in data collection (Creswell, 2003), have pointed to the design of a sample survey (Tan, 2002) for this study. Only local contractors were chosen to participate in the survey because of the requirement to achieve cultural uniformity and representativeness of the sample as the study entails cultural response from the participants. The participation of only local contractors would remove the problem of "imposed etic" (after Berry, 1990) by foreign respondents which would potentially disturb the uniformity in the cultural background of responses for analysis. 
The requirement of adequacy in the level of quality management's sophistication and the industry representation of being the main players in the local construction industry have led to the choice of medium- to large-sized contractors for the sample. The former consideration is in line with Saraph et al's (1989) assertion of choosing medium- to large-sized firms to be studied as the quality management practices of small firms are likely to be relatively unsophisticated or highly variable. The latter consideration corresponds with Low and Fong's (2002) proposition that contractors with grades G6 to G8 according to the Singapore's Building and Construction Authority (BCA) Central Registry of Public Sector Contractors are the main players in the industry. These grades represent medium- to large-sized contractors. (BCA had subsequently changed the classification of grades from G1 to G8, to C3 to A1 respectively (loosely) with A1 represents the highest grade!) Accordingly, in relation to the new classification, only contractors with grades A1 to A2 (as large contractors), and B1 to B2 (as medium-sized contractors) were included as sample for the study (C1 to C3 contractors were taken to be small contractors). The characteristics and composition of the contractors forming the sample are given in Table 2.

As shown in Table 2, due to the small sample size, all of the 145 local contractors were invited to participate in the study. The participation was solicited through the company's managerial, professional, and executive personnel. In line with Maloney and Federle’s (1993) suggestion, multiple responses from various respondents pivoting around a willing manager dispersing out to the manager's superior, peers, and subordinates were sought from a single company. The questionnaires were dispatched in the middle of July 2003 and a follow-up was 
effected in December 2003 and January 2004. The final date for data collection was February 2004. 56 responses were received and were subsequently used in the statistical analyses.

\section{Questionnaire design}

The questions pertaining to organizational culture utilize the Organizational Culture Assessment Instrument (OCAI) developed by Cameron and Quinn (1998) under the Competing Values Framework (CVF) of cultural study. The instrument "measures" organizational culture with six content dimensions in the form of statements that dictate scenarios of organizational phenomena (hence the scenario analysis) (see Table 1 for the scenarios/questions asked for each ideal type). A respondent rates the level of similarity the statements resemble the current situation in his/her organization in the Likert-like scales (Quinn and Speitzer, 1991). Each statement under a content dimension is associated with one cultural type as identified in the CVF. The completion of the OCAI provides a picture of the organizational culture and the values that characterize it (Cameron and Quinn, 1998). For example, under the content dimension of "Organizational leadership,” the statement "The leadership in the organization is generally considered to exemplify mentoring, facilitating or nurturing” is associated with the clan culture. High scoring of this statement indicates that the respondent's organization demonstrates strong characteristic of clan culture!

For TQM, the statements on various practices are presented and their level of implementation sought. The statements were eclectically constructed from a series of published literature involving empirical research on the implementation of TQM practices (Saraph et al, 1989; Flynn et al, 1994; Ahire et al, 1996; Black 
and Porter, 1996; and Claver et al, 2002), construction organizational learning (Kululanga et al, 2002), and relationship marketing (Low and Tan, 2002). In all of these literatures, items that are relevant to the construction context that fall into the eight TQM domains identified earlier were used in the present study. Modifications were performed on the statements to be couched in the manner befitting construction settings.

\section{DATA ANALYSES AND DISCUSSIONS}

\section{Profiles of respondents and companies}

The characteristics of the respondents and their companies are given in Figure 1. "MR" in Figure 1 a) denotes "Management Representative”. The distributions of designations of the respondents are rather uniform among the three managerial strata. While all contractors are active in more than one project type, residential projects appear to be the most popular project type (Figure $1 \mathrm{~b}$ )) among the contractors. The characteristics of staff strength (Figure $1 \mathrm{c}$ )) and annual turnover (Figure 1d)) have indicated that a majority of the contractors are of medium firm size (and possibly small size too). This observation is in line with the situation in other countries where the construction industry is predominantly constituted by smaller firms (see for example Eccles, 1981; Barthorpe, 2002). In addition, as shown in Figure 1 e), the majority of the contractors are from the "medium" category of B1 and B2 (68\% combined).

\section{The organizational culture clusters}

The hierarchical procedure of cluster analysis using Ward's clustering method was performed on the data from the OCAI section (i.e. the section on 
organizational culture). In Ward's method, the "similarity" measure is the distance between two clusters. This distance is calculated as the sum of squares between the two adjacent clusters summed over all variables used to characterize groups (Hair et al., 1998: 473, 496). Further checks with the non-hierarchical clustering method and discriminant analysis using TQM elements of top management leadership and people management to test the predictive validity of the proposed solution have indicated that the 4-cluster solution is a reasonably stable solution for the present study. These 4 clusters, together with their proposed label and their main characteristics are given in Table 3.

In Table 3, the means scores of each cultural type in relation to the CVF's cultural content dimensions on each original ideal type are presented. The means scores are calculated by averaging the scores on the statements under the content dimensions with respect to each ideal type for all cases. The numbers in parentheses represent the number of cases in each cluster and their corresponding percentage. The emergent cultural clusters are trisected into high, moderate, and low to facilitate interpretation. The means scores for "High" is "means $\geq 3.70$ ", for "Moderate" is " $2.80 \leq$ means $<3.70$ ", and for "Low" is "means $<2.80$ ". With the trisection, the clusters are labelled as "Hierarchy-driven culture" in Cluster 1, “Clan-driven culture” in Cluster 2, "Strong comprehensive culture” in Cluster 3, and "Weak comprehensive culture" in Cluster 4. By comparing the emergent organizational culture types against the CVF ideal types, it is clear that firms are seldom characterized by a single cultural type. That is, there is no indication that one particular cultural ideal type and its traits (e.g. clan) are scored highly while 
the cultural traits of other ideal types are not scored or are scored at a very low level. Most often, they are represented by a combination of different ideal types.

Of the four emergent cultural types, the Strong and Weak Comprehensive Cultures are of particular interest. In the Strong Comprehensive Culture, almost all competing sides of the original ideal types are equally emphasized (see Table 3). This cultural orientation may have engendered the demanding tasks of managing the tensions and paradoxes inherent in the culture. With the high clan and hierarchy, high market, and moderate adhocracy cultural traits, this emergent cultural type experiences simultaneous competing demands of internal and external orientations. In addition, this culture also faces structural requirements of both flexibility and control.

Companies with Weak Comprehensive Culture have low adhocracy and market cultural traits while moderate clan and hierarchy traits. The means scores in Table 3 indicate that the companies with this cultural type emphasize moderately internal orientation (i.e. the clan and hierarchy) but are weak in external orientation. Accordingly, these firms may lack the dynamism required to face the volatile conditions and may not be as competitive as firms with other cultural orientation.

\section{Cultural cluster and TQM practices}

A series of ANOVAs were conducted to determine the differences among the emergent cultural types with the implementation of TQM (after Yeung et al, 1991). ANOVA tests for the differences in the means of the four emergent cultural types (i.e. the groups) on the implementation of TQM practices. In addition, it also tests if the differences among the groups are significant. Hence, 
ANOVA can be used to test the hypotheses of the study (see next section). The results of the ANOVAs are given in Table 4.

\section{TQM practices across cultural types}

As shown in Table 4, there are significant differences among TQM elements across different cultural types. Hypothesis 1 is therefore supported in that TQM practices in organization with different dominant cultural types are significantly different (as shown in Table 4 with high $F$-value at $p<0.05$ ). Further, it can be discerned that the TQM implementation level in all elements for the "Strong comprehensive culture" is the highest, follows by the "Clan-driven culture", then the "Hierarchy-driven culture”, and lastly the "Weak comprehensive culture”. This pattern suggests that different TQM practices in organization with different dominant cultural types are differentially emphasized.

Most emergent cultural types, with the exception of the strong comprehensive culture, are weak in quality information management. Shammas-Toma et al's (1998) report on the absence of measurable quality criteria to monitor improvement may have manifested such low implementation of quality information management. On the contrary, except the weak comprehensive culture, customer management is highly implemented with most of the cultural types signifying that most contractors may have come to realize the benefits with the higher implementation of customer management.

The implementation of the four TQM elements of people management, continual improvement, quality information management, and organizational learning are at the relatively lower levels. These four elements are consistently ranked 5, 6, 7, and 8 (not in particular order) in their implementation levels. The 
lower ranking of these elements suggests that the implementation level of these perceivably newer TQM elements is somewhat lacking if compared with the more traditional elements of customer management, top management leadership, process management, and supplier management. This points to the lack of attention, understanding, and appreciation of the newer TQM elements. The overall lowly to moderately implemented people management suggests that contractors embrace only marginally the human resource management.

While high implementation level of TQM elements are discernable in the strong comprehensive culture and to certain extent, the clan-driven culture, there is no particularly high level of implementation level on any element with the hierarchy-driven and weak comprehensive cultures. This observation partially supports Hypothesis 2 as it posits that organizations at the high level of TQM implementation will demonstrate similar cultural characteristics. The Hypothesis holds true for organizations with the strong comprehensive culture, and again, to a certain extent, the organizations with the clan-driven culture (with their high implementation of process management), the situations with the hierarchy-driven and weak comprehensive cultures do not support the Hypothesis. Indeed, their implementation levels of most elements are so mediocre that there are no clear indications of their preferred or strong elements! With retrospection, however, the persistently moderate to low level of TQM implementation for these two cultural types represent a "pattern" that is not conducive to TQM implementation.

\section{TQM practices for each cultural type}

\section{Strong comprehensive culture}


The high implementation level of process management (see Table 4 for actual ranking and mean score), indeed, the highest level among all the eight TQM elements for this cultural type appears to be the contribution of its high hierarchy cultural characteristics. In addition, the high characterization of the market culture and moderate characterization of adhocracy culture have contributed to the high implementation of customer and supplier management with the externally oriented behaviour of the two cultural ideal types. However, despite high characterization of the clan culture, this emergent cultural type only implements moderately-highly people management instead of the expected high level.

The moderate level characterization of adhocracy culture in the strong comprehensive culture implies that even the strong and well-rounded contractors among the four emergent cultural groups fare only marginally in the area of creativity, flexibility, innovativeness, and adaptability. These may have translated into the relatively lower implementation level of continual improvement and organizational learning (jointly ranked 6, see Table 4), and quality information management as these TQM elements acts as catalysts for the continual improvement initiatives based on the forces and demands for the organizations to be creative and flexible. Indeed, the lack of organizations with adhocracy- and market-driven cultures, and over one-third of contractors are having hierarchydriven culture in this sample may have indicated the lack of total flexibility and adaptability among local contractors. Further, the pattern also points to the fact that most local contractors (except contractors with strong comprehensive culture) are internally focused and controlled oriented. As noted by Yeung et al (1991), the prevailing cultural orientations may have been the results of the contractors' scale 
of operation, the industrial environments of construction, and the historical development. Nevertheless, with an increasingly more competitive and tumultuous environment, contractors need to reassess the suitability of their organizational culture. Striving to emulate the contractors with the strong comprehensive culture may serve as a first step.

\section{Clan-driven culture}

The culture's moderate implementation level of people management and its high level implementation of process management are somewhat unexpected. The central human resource theme in relation to the clan culture does not quite manifest itself. The high implementation level of process management can be interpreted as the general pattern of high level implementation for this element across the emergent cultural types (except the weak comprehensive culture). The moderate level of hierarchy cultural traits may have also contributed to this pattern of high level process management.

The dominant clan cultural traits have conferred some degree of flexibility in the clan-driven culture. Although somewhat internally focused, its moderate level of cultural characteristics from the adhocracy and market cultures have contributed to the pattern of implementation manifested in customer and supplier management which are externally oriented.

\section{Hierarchy-driven culture}

While the implementation level of process management for this emergent culture type is expected with its perceivably more mechanistic orientation as a result of high hierarchical inclination, its moderately-highly implementation level of customer management and top management leadership is a surprise. The 
implementation pattern suggests that although this emergent cultural type is dominated by the hierarchy culture, it does not demonstrate totally the negativities associated with the pure hierarchy culture (i.e. internally focused and controlled orientation). This observation has underpinned the notion of simultaneous presence of other cultural traits that have somewhat mitigated the negative impact of the pure hierarchy cultural type.

\section{Weak comprehensive culture}

For the TQM elements that are implemented at the moderate level, half of the proportion of their ranges is at the lower threshold of the moderate level with their mean ratings less than the medium rating of 3 (see Table 4). The moderate clan cultural traits also contribute to the low implementation level of people management. Further, the low adhocracy and market cultural characteristics have also resulted to (only) moderate implementation level of customer and supplier management.

The fact that $25 \%$ of the contractors in this sample are categorized under this emergent cultural group is rather alarming considering construction industry's volatile and turbulent conditions. It is unclear how the organizations with the weak comprehensive culture operate with their seemingly lacking ingredients in response to the environmental challenges.

\section{CONCLUSIONS AND RECOMMENDATIONS}

A balanced and strong organizational culture (as in the strong comprehensive culture) facilitates TQM implementation with its simultaneous internal/external and flexible/controlled orientations. But more importantly, the results have 
underscored the importance of balancing the cultural values across the four cultural ideal types. While a particular cultural orientation is not inherently wrong, it may not be conducive for the overall implementation of TQM practices. It is suggested that the cultural orientation of a firm be balanced across the four cultural ideal types.

While only four emergent cultural types were identified in this study, there may be other type of cultural profiles with their TQM implementation patterns among construction firms. Further studies can hence be conducted as follows:

- Studies can be conducted with larger sample size to examine the existence of other cultural types with their associated TQM implementation pattern.

- As the present study investigates only the relationships between the two variables, future study can be conducted to examine the causality between organizational culture and TQM implementation so that more accurate and better structured strategies can be formulated. This can also serve to validate the present study.

- Empirical study can be conducted to examine the relationships between organizational culture and TQM practices, and the company's competitiveness (e.g. Powell, 1995).

- As present study covers only individual firm, the instrument adopted here can be used to investigate construction project-wide culture so that strategies can be devised to address the quality management issues inherent in the multi-party project environment.

The use of questionnaire survey for a cultural study is controversial. While the constraints encountered in the study have necessitated the use of survey, it is 
acknowledged that the issues on the lack of depth, the questionable content validity in association with the interpretation and the use of the cultural instrument developed in other cultural environment, and the part-whole fallacy (Martin, 2002) are present and may have contentiously affected the representativeness of the study. This study has nevertheless demonstrated the possible relationships between the organizational culture and TQM implementation in the construction organizational setting.

\section{Recommendations}

Based on the findings, two strategies may be recommended:

1. Modification of organizational culture in response to the diagnosis on the weak cultural aspects that requires fortification.

2. Adaptation of TQM practices to better suit the prevailing organizational culture so that quick results can be attained.

While it is possible that these two strategies are alternatives among themselves, it is more plausible that they are implemented in a simultaneous or sequential manner. In the latter scenario, modifications of organizational culture are to be taken place prior to the adaptation of TQM practices since cultural change is almost always the prerequisite of TQM implementation.

Figure 2 shows the cultural-based TQM implementation strategies. The modification of the organizational culture aims to nudge the organizations towards achieving strong comprehensive culture. Specifically, companies are encouraged to adopt a more externally oriented outlook and flexible structure in order to be aligned with the TQM simultaneous internal/external orientation. 
Because cultural modification is a long-term endeavour even in the simultaneous approach, the shorter-term strategy that the companies can adopt is to affect changes in TQM practices that could yield relatively quick results. The recommendations for TQM modifications are first directed on the practices that the companies implement at a considerable level with respect to their emergent culture, follow by other more lowly implemented practices. This approach exploits the relationship between the organizational culture and TQM implementation recognizing that organization implements practices better in the area where the values associated with the practices are in alignment with the culture prevailing in the organization - the "least-resistance” route (Kekäle and Kekäle, 1995; Kekäle, 1999). The “feel-good” factor with the improved TQM implementation can then be cascaded to the remaining practices. For example, in organization with “hierarchy-driven culture,” there is low emphasis on external orientation and high level implementation of customer and process management. It is recommended that the organization modifies its cultural orientation to be more flexible and externally oriented while strengthening the customer and process management first. After these initial results are obtained, the organization can then proceed to improve other TQM practices. 


\section{REFERENCES}

Ahire, S.L., Golhar, D.Y., and Waller, M.A. (1996) Development and validation of TQM implementation constructs. Decision Sciences, 27(1), 23-56.

Anderson, J.C., Rungtusanathan, M. and Schroeder, R.G. (1994) A theory of quality management underlying the Deming management method. Academy of Management Review, 19(3), 472-509.

Barthorpe, S. (2002) The origins and organizational perspectives of culture, in Seymour, D.E. and Fellows, R.F. (Eds.) Perspective on Culture in Construction, CIB Publication No.275, CIB TG23, Rotterdam, The Netherlands, pp.7-24.

BCA. (2003, Jul.) BCA contractors registry. Singapore: BCA. Retrieved 18 July 2003 from http://dir.bca.gov.sg/bca/index.asp\#

BCA. (2004, Jul.) Registration requirements for construction workheads (CW), July 2004 edition. Singapore: BCA. Retrieved 8 October from http://dir.bca.gov.sg/bca/Regist.asp

Berry, J.W. (1990) Imposed etics, emics, and derived etics: Their conceptual and operational status in cross-cultural psychology, in Headland, T.N., Pike, K.L., and Harris, M. (Eds.) Emics and Etics: The Insider/Outsider Debate. Sage Publications, Newbury Park, CA, pp.84-99.

Black, S.A. and Porter, L.J. (1996) Identification of the critical factors of TQM. Decision Science, 27(1), 1-21.

Burati, J.L., Matthews, M.F., and Kalidindi, S.N. (1992) Quality management organizations and techniques. Journal of Construction Engineering \& Management, 118(1), 112-128.

Cameron, K.S. and Quinn, R.E. (1998) Diagnosing and Changing Organizational Culture Based on the Competing Values Framework. Addison Wesley, Reading, MA.

Chase, G.W. (1993) Effective total quality management (TQM) process for construction. Journal of Management in Engineering, 9(4), 433-443.

Chiles, T.H. and Choi, T.Y. (2000) Theorizing TQM: An Austrian and evolutionary economics interpretation. Journal of Management Studies, 37(2), 185-212.

Claver, E., Tari, J.J., and Molina, F. (2002) Areas of improvement in certified firms advancing towards TQM. International Journal of Quality \& Reliability Management, 19(8/9), 1014-1036. 
Creswell, J.W. (2003) Research design: Qualitative, quantitative, and mixed method. Sage Publications, Thousand Oaks, CA.

Crosby, P.B. (1979) Quality is Free: The Art of Making Quality Certain. McGraw-Hill, New York.

Dean, J.W.Jr. and Bowen, D.E. (1994) Management theory and total quality: Improving research and practice through theory development. Academy of Management Review, 19(3), 392-418.

Deming, W.E. (1986) Out of the Crisis. MIT Center for Advanced Engineering. Cambridge, MA.

Demski, S. (1993) Resistance to change: Why your TQM efforts may fail. Journal of Management in Engineering. 9(4), 426-432.

Denison, D.R. and Spreitzer, G.M. (1991) Organizational culture and organizational development: A competing values approach, in Woodman, R.W. and Pasmore, W.A. (Eds.) Research in Organizational Change and Development, Vol. 5, JAI Press, Greenwich, Connecticut, pp.1-21.

Detert, J.R., Schroeder, R.G., and Mauriel, J.J. (2000) A framework for linking culture and improvement initiatives in organizations. Academy of Management Review, 25(4), 850-863.

Drazin, R. and Van de Ven, A.H. (1985) Alternative forms of fit in contingency theory. Administrative Science Quarterly, 30(4), 514-539.

Eccles, R.G. (1981) Bureaucratic versus craft administration: The relationship of market structure to the construction firm. Administrative Science Quarterly, 26(3), 449-469.

Federle, M.O. and Chase, G.W. (1993) Applying Total Quality Management to design and construction. Journal of Management in Engineering, 9(4), 357-364.

Feigenbaum, A.V. (1983) Total Quality Control, $3^{\text {rd }}$. Edition. McGraw-Hill, New York.

Flynn, B.B., Schroeder, R.G., and Sakakibara, S. (1994) A framework for quality management research and an associated measurement instrument. Journal of Operations Management, 11(4), 339-366.

Hackman, J.R. and Wageman, R. (1995) Total quality management: Empirical, conceptual, and practical issues. Administrative Science Quarterly, 40(2), 309-342. 
Hair, J.F.J., Anderson, R.E., Tatham, R.L., and Black, W.C. (1998) Multivariate Data Analysis, $5^{\text {th }}$. Edition. Prentice Hall, Upper Saddle River, NJ.

Hofstede, G. (2001) Culture's Consequences: Comparing Values, Behaviors, Institutions, and Organizations Across Nations, $2^{\text {nd }}$. Edition. Sage Publications, Thousand Oaks, CA.

Ishikawa, K. (1985) What is Total Quality Control? The Japanese Way. Prentice Hall, Englewood Cliffs, NJ.

Juran, J.M. and Gryna, F.M. (1980) Quality Planning and Analysis: From Product Development Through Use, $2^{\text {nd }}$. Edition. McGraw-Hill, New York.

Kekäle, T. and Kekäle, J. (1995) A mismatch of cultures: Pitfall of implementing a total quality approach. International Journal of Quality \& Reliability Management, 12(9), 210-220.

Kekäle, T. (1999). The effects of organizational culture on success and failures in implementation of some total quality approaches. Bristol Business School Teaching and Research Review, 1, available at http://www.uwe.ac.uk/bbs/trr/Issue1/IS1-1_1.htm

Kululanga, G.K., Price, A.D.F., and McCaffer, R. (2002) Empirical investigation of construction contractors' organizational learning. Journal of Construction Engineering \& Management, 128(5), 385-391.

Love, P.E.D. and Li, H. (2000) Overcoming the problems associated with quality certification. Construction Management \& Economics, 18(2), 139-149.

Low, S.P. and Fong, E.T.W. (2002) Preparations for ISO9001-2000 - A study of ISO9000: 1994 certified construction firms. Construction Management \& Economics, 20(5), 403-413.

Low, S.P. and Tan, S.L.G. (2002) Relationship marketing: A survey of QS firms in Singapore. Construction Management \& Economics, 20(8), 707-721.

Low, S.P. and Teo, J.A. (2004) Implementing Total Quality Management in construction firms. Journal of Management in Engineering, 20(1), 8-15.

Maloney, W.F. and Federle, M.O. (1993) Practical models for organizational assessment. Journal of Management in Engineering, 9(1), 64-81.

Martin, J. (2002) Organizational Culture: Mapping the Terrain. Sage Publications, Thousand Oaks, California.

Mathews, B.P., Ueno, A., Kekale, T., Repka, M., Pereira, Z.L., and Silva, G. (2001) European quality management practices: The impact of national 
culture. International Journal of Quality \& Reliability Management, 18(7), 692-707.

McNabb, D.E. and Sepic, F.T. (1995) Culture, climate, and total quality management: Measuring readiness for change. Public Productivity \& Management Review, 18(4), 369-385.

Nadler, D.A. and Tushman, M.L. (1980) A model of diagnosing organization behaviour. Organizational Dynamics, 9(2), 35-51.

Powell, T.C. (1995). Total quality management as competitive advantage: A review and empirical study. Strategic Management Journal, 16(1), 15-37.

Quinn, R.E. and Spreitzer, G.M. (1991) The psychometrics of the competing values culture instrument and an analysis of the impact of organizational culture on quality of life, in Woodman, R.W. and Pasmore, W.A. (Eds.) Research in Organizational Change and Development, Vol. 5, JAI Press, Greenwich, Connecticut, pp.115-142.

Roney, J. (1997) Cultural implications of implementing TQM in Poland. Journal of World Business, 32(2), 152-168.

Rousseau, D.M. (1990) Assessing organizational culture: The case for multiple methods, in Schneider, B. (Ed.), Organizational Climate and Culture, Jossey-Bass, San Francisco, CA, pp.153-192.

Saraph, J.V., Benson, P.G., and Schroeder, R.G. (1989) An instrument for measuring the critical factors of quality management. Decision Sciences, 20(4), 810-829.

Schein, E.H. (1985) Organizational Culture and Leadership. Jossey-Bass, San Francisco.

Shammas-Toma, M., Seymour, D., and Clark, L. (1998). Obstacles to implementing total quality management in the UK construction industry. Construction Management \& Economics, 16(2), 177-192.

Sinclair, J. and Collins, D. (1994). Towards a quality culture? International Journal of Quality \& Reliability Management, 11(5), 19-29.

Sousa-Poza, A., Nystrom, H., and Wiebe, H. (2001). A cross-cultural study of the differing effects of corporate culture on TQM in three countries. International Journal of Quality \& Reliability Management, 18(7), 744746.

Spencer, B.A. (1994). Models of organization and total quality management: A comparison and critical evaluation. Academy of Management Review, 19(3), 446-471. 
Tan, W. (2002). Practical Research Methods. Prentice Hall, Pearson Education. Singapore.

Van de Ven, A. and Drazin, R. (1985) The concept of fit in contingency theory, in Staw, B.M. and Cummings, L.L. (Eds.) Research in Organizational Behaviour, Vol. 7, JAI Press, Greenwich, CT, pp.333-365.

Yeung, A.K.O., Brockbank, J.W. and Ulrich, D.O. (1991) Organizational culture and human resource practices: An empirical assessment, in Woodman, R.W. and Pasmore, W.A. (Eds.) Research in Organizational Change and Development, Vol. 5, JAI Press, Greenwich, Connecticut, pp.59-81.

Zammuto, R.F., Gifford, B., and Goodman, E.A. (2000) Managerial ideologies, organization culture, and the outcomes of innovation, in Ashkanasy, N.M, Wilderom, C.P.M., and Peterson, M.F. (Eds.) Handbook of Organizational Culture and Climate, Sage Publications, Thousand Oaks, CA, pp.261-278.

Zammuto, R.F. and Krakower, J.Y. (1991) Quantitative and qualitative studies of organizational culture, in Woodman, R.W. and Pasmore, W.A. (Eds.) Research in Organizational Change and Development, Vol. 5, JAI Press, Greenwich, Connecticut, pp.83-114.

\section{LIST OF FIGURES AND TABLES}

Figure 1 Profiles of the responding companies

Figure 2 A cultural-based TQM implementation strategies

Table 1 Main characteristics of the culture ideal types

Table 2 Characteristics and composition of sample

Table 3 Means scores of culture clusters against CVF ideal types

Table 4 TQM practices in different cultural clusters 
a) Designation of respondent

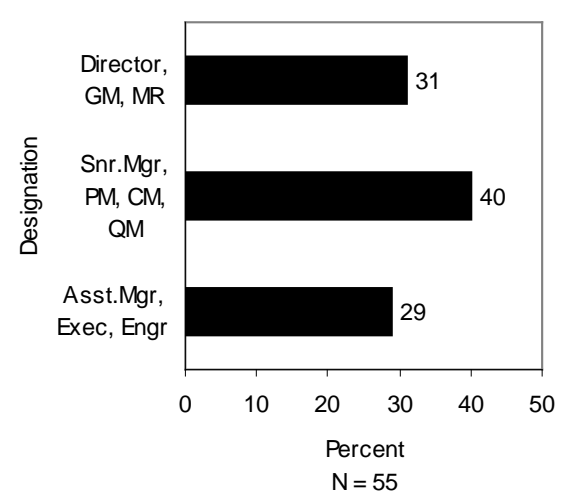

c) Number of staff

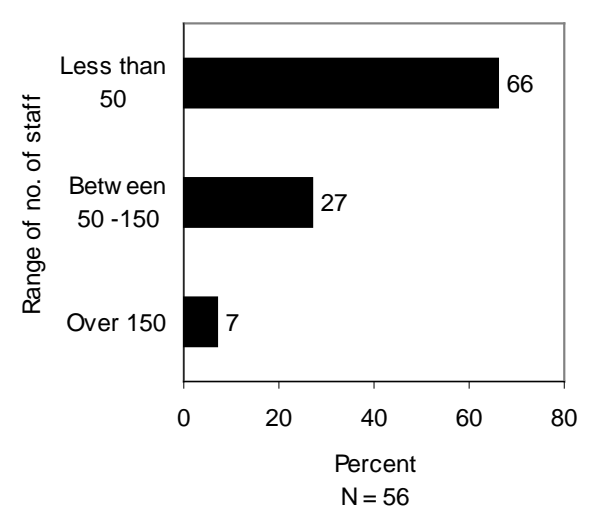

e) $B C A$ registration grade

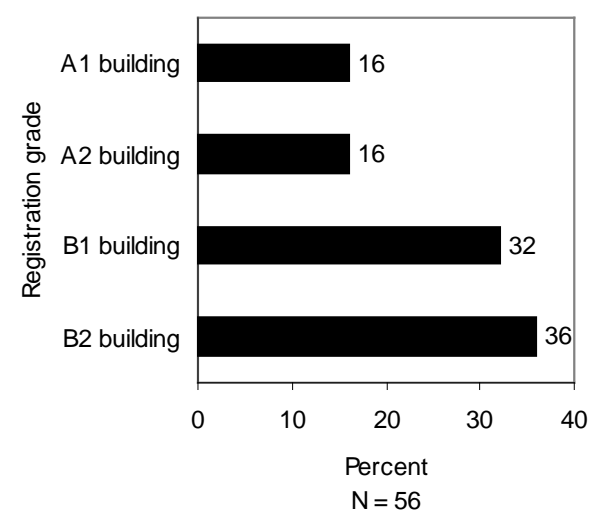

b) Scope of business

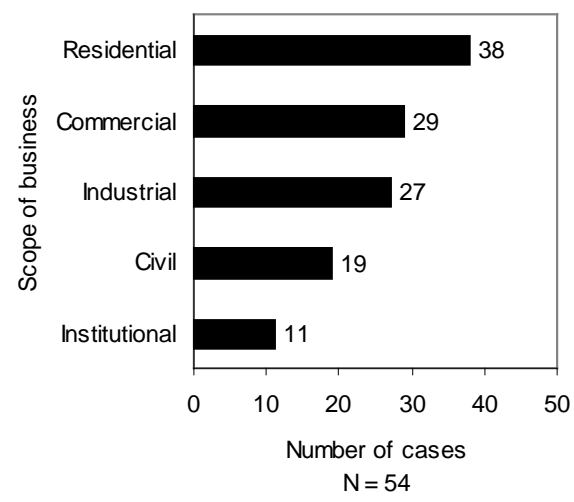

d) Annual turnover

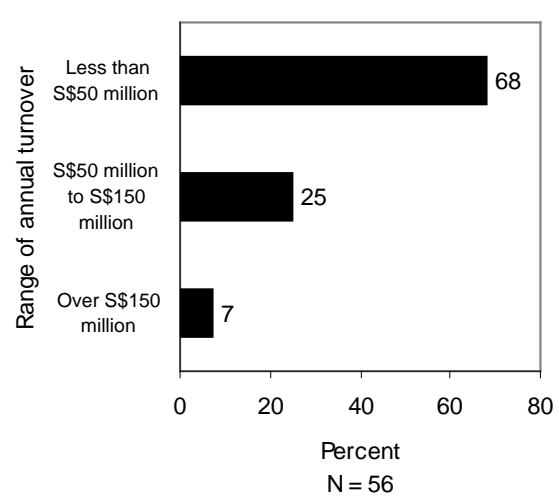

Figure 1 Profiles of the responding companies 
Organizational culture profiles

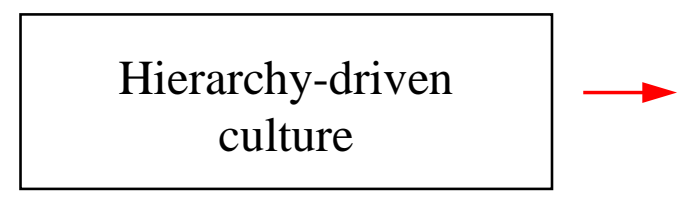

\section{Clan-driven culture}

Strong comprehensive culture

Weak comprehensive culture
Possible implementation strategies

1. Modify culture to be more flexible and externally oriented.

2. Fortify customer and process management first, follow by other elements.

1. Modify culture to be more externally oriented.

2. Fortify customer and process management first, follow by other elements.

1. Maintain current culture.

2. Maintain current TQM level first, fortify quality information management.

1. Fortify all areas of flexibility and external orientation.

2. Fortify supplier, customer, and process management first, follow by other elements.

Figure 2 A cultural-based TQM implementation strategies 
Table 1 Main characteristics of the culture ideal types

\begin{tabular}{|c|c|c|c|c|}
\hline \multirow[b]{2}{*}{$\begin{array}{l}\text { Content } \\
\text { dimension }\end{array}$} & \multicolumn{4}{|c|}{ Ideal type } \\
\hline & Hierarchy & Clan & Adhocracy & Market \\
\hline $\begin{array}{l}\text { The } \\
\text { organization } \\
\text { is: }\end{array}$ & $\begin{array}{l}\text { Controlled and } \\
\text { structured with } \\
\text { formal } \\
\text { procedures }\end{array}$ & $\begin{array}{l}\text { A personal place, } \\
\text { an extended and } \\
\text { sharing family }\end{array}$ & $\begin{array}{l}\text { A dynamic and } \\
\text { entrepreneurial } \\
\text { place }\end{array}$ & $\begin{array}{l}\text { Very results } \\
\text { oriented, people are } \\
\text { competitive }\end{array}$ \\
\hline $\begin{array}{l}\text { The leadership } \\
\text { is: }\end{array}$ & $\begin{array}{l}\text { Focused on } \\
\text { coordinating, and } \\
\text { efficiency }\end{array}$ & $\begin{array}{l}\text { Mentoring, } \\
\text { facilitating, and } \\
\text { nurturing }\end{array}$ & $\begin{array}{l}\text { Entrepreneurial, } \\
\text { innovative, and } \\
\text { risk-taking }\end{array}$ & $\begin{array}{l}\text { Aggressive, result- } \\
\text { oriented, and no- } \\
\text { nonsense }\end{array}$ \\
\hline $\begin{array}{l}\text { Employee ma- } \\
\text { nagement is } \\
\text { characterized } \\
\text { by: }\end{array}$ & $\begin{array}{l}\text { Security of } \\
\text { employment, } \\
\text { conformity. }\end{array}$ & $\begin{array}{l}\text { Teamwork, } \\
\text { consensus, and } \\
\text { participation }\end{array}$ & $\begin{array}{l}\text { Individual risk- } \\
\text { taking, } \\
\text { uniqueness and } \\
\text { innovative }\end{array}$ & $\begin{array}{l}\text { Hard-driving } \\
\text { competitiveness, } \\
\text { and achievement }\end{array}$ \\
\hline $\begin{array}{l}\text { Organization } \\
\text { is held } \\
\text { together by: }\end{array}$ & $\begin{array}{l}\text { Formal rules and } \\
\text { policies }\end{array}$ & $\begin{array}{l}\text { Loyalty, mutual } \\
\text { trust, personal } \\
\text { commitment }\end{array}$ & $\begin{array}{l}\text { Commitment to } \\
\text { innovation and } \\
\text { development }\end{array}$ & $\begin{array}{l}\text { Emphasis on goal } \\
\text { accomplishment } \\
\text { and achievement }\end{array}$ \\
\hline $\begin{array}{l}\text { The strategic } \\
\text { emphases are: }\end{array}$ & $\begin{array}{l}\text { Permanency, } \\
\text { stability, and } \\
\text { efficiency }\end{array}$ & $\begin{array}{l}\text { Openness, human } \\
\text { development, } \\
\text { high trust, } \\
\text { participation }\end{array}$ & $\begin{array}{l}\text { Acquisition of } \\
\text { new resources, } \\
\text { creating new } \\
\text { thing }\end{array}$ & $\begin{array}{l}\text { Competitive actions } \\
\text { and achievement }\end{array}$ \\
\hline $\begin{array}{l}\text { Criteria of } \\
\text { success are: }\end{array}$ & $\begin{array}{l}\text { Operational } \\
\text { efficiency }\end{array}$ & $\begin{array}{l}\text { Development of } \\
\text { human resource }\end{array}$ & $\begin{array}{l}\text { Having the most } \\
\text { unique or newest } \\
\text { product }\end{array}$ & $\begin{array}{l}\text { Winning in the } \\
\text { market, outpacing } \\
\text { the competition }\end{array}$ \\
\hline
\end{tabular}

(Adapted from Cameron and Quinn, 1998; Denison and Spreitzer, 1991; Zammuto et al, 2000) 
Table 2 Characteristics and composition of sample

\begin{tabular}{|c|c|c|c|c|}
\hline BCA grades & $\begin{array}{c}\text { Tendering } \\
\text { limit* }\end{array}$ & $\begin{array}{l}\text { Min. paid- } \\
\text { up capital } \\
\text { and min. } \\
\text { net worth* }\end{array}$ & $\begin{array}{l}\text { Sample } \\
\text { category } \\
\text { size (local } \\
\text { only)** }\end{array}$ & $\begin{array}{l}\text { Total in } \\
\text { category } \\
\text { (both local } \\
\text { and } \\
\text { foreign)** }\end{array}$ \\
\hline A1 & Unlimited & $\begin{array}{l}\mathrm{S} \$ 15.00 \\
\text { million }\end{array}$ & 24 & 35 \\
\hline A2 & $\begin{array}{l}\text { S\$65.00 } \\
\text { million }\end{array}$ & $\begin{array}{l}\mathrm{S} \$ 6.50 \\
\text { million }\end{array}$ & 22 & 25 \\
\hline B1 & $\begin{array}{l}\text { S\$30.00 } \\
\text { million }\end{array}$ & $\begin{array}{l}\text { S\$3.00 } \\
\text { million }\end{array}$ & 52 & 71 \\
\hline B2 & $\begin{array}{l}\mathrm{S} \$ 10.00 \\
\text { million }\end{array}$ & $\begin{array}{l}\mathrm{S} \$ 1.00 \\
\text { million }\end{array}$ & 47 & 74 \\
\hline Total & -- & -- & 145 & 205 \\
\hline
\end{tabular}

(Source *: BCA, 2004, October, Registration requirements for construction workheads, **: BCA, 2003, July, BCA contractors registry) 
Table 3 Means scores of cultural clusters against CVF ideal types

\begin{tabular}{|c|c|c|c|c|c|}
\hline & \multicolumn{4}{|c|}{ Emergent cultural clusters and their characteristics } & \multirow[b]{2}{*}{$\begin{array}{c}\boldsymbol{F} \text { - } \\
\text { value* }^{*}\end{array}$} \\
\hline $\begin{array}{c}\text { Original } \\
\text { cultural ideal } \\
\text { types }\end{array}$ & $\begin{array}{c}\text { Cluster } 1 \\
\text { (19, 34\%) } \\
\text { Hierarchy- } \\
\text { driven }\end{array}$ & $\begin{array}{c}\text { Cluster } 2 \\
(8,14 \%) \\
\text { Clan- } \\
\text { driven }\end{array}$ & $\begin{array}{c}\text { Cluster } 3 \\
\text { (15, 27\%) } \\
\text { Strong } \\
\text { comprehensive }\end{array}$ & $\begin{array}{c}\text { Cluster } 4 \\
(14,25 \%) \\
\text { Weak } \\
\text { comprehensive }\end{array}$ & \\
\hline CLAN & $\begin{array}{c}3.20 \\
\text { (Mod.) }\end{array}$ & $\begin{array}{c}3.73 \\
\text { (High) }\end{array}$ & $\begin{array}{c}4.00 \\
\text { (High) }\end{array}$ & $\begin{array}{c}2.85 \\
\text { (Mod.) }\end{array}$ & 16.43 \\
\hline ADHOCRACY & $\begin{array}{l}2.51 \\
\text { (Low) }\end{array}$ & $\begin{array}{c}3.29 \\
\text { (Mod.) }\end{array}$ & $\begin{array}{c}3.50 \\
\text { (Mod.) }\end{array}$ & $\begin{array}{l}2.37 \\
\text { (Low) }\end{array}$ & 34.98 \\
\hline MARKET & $\begin{array}{c}3.37 \\
\text { (Mod.) }\end{array}$ & $\begin{array}{c}3.21 \\
\text { (Mod.) }\end{array}$ & $\begin{array}{c}3.91 \\
\text { (High) }\end{array}$ & $\begin{array}{l}2.70 \\
\text { (Low) }\end{array}$ & 25.09 \\
\hline HIERARCHY & $\begin{array}{l}3.80 \\
\text { (High) }\end{array}$ & $\begin{array}{c}3.12 \\
\text { (Mod.) }\end{array}$ & $\begin{array}{c}3.99 \\
\text { (High) }\end{array}$ & $\begin{array}{c}2.88 \\
\text { (Mod.) }\end{array}$ & 32.05 \\
\hline & $\begin{array}{l}\text { Firms } \\
\text { consider } \\
\text { volatility in } \\
\text { construction } \\
\text { can best be } \\
\text { managed with } \\
\text { internal rules } \\
\text { and } \\
\text { operations. } \\
\text { Low } \\
\text { emphasis on } \\
\text { external } \\
\text { orientation, } \\
\text { innovation, } \\
\text { and creativity. }\end{array}$ & $\begin{array}{l}\text { "Moderate } \\
\text { comprehensive } \\
\text { culture". } \\
\text { Internally } \\
\text { focused. } \\
\text { Certain degree } \\
\text { of } \\
\text { innovativeness, } \\
\text { adaptability, } \\
\text { and market } \\
\text { orientation. } \\
\text { More flexible. }\end{array}$ & $\begin{array}{l}\text { Firms focus } \\
\text { simultaneous } \\
\text { competing } \\
\text { demands of } \\
\text { internal and } \\
\text { external } \\
\text { orientations, and } \\
\text { flexible and } \\
\text { controlled } \\
\text { organizational } \\
\text { structure, but } \\
\text { may be suitable } \\
\text { for TQM } \\
\text { implementation } \\
\text { and construction } \\
\text { volatility. }\end{array}$ & $\begin{array}{l}\text { Moderately } \\
\text { internally } \\
\text { focused. } \\
\text { Weak in external } \\
\text { orientation. } \\
\text { Firm may lack } \\
\text { capacity to be } \\
\text { innovative and } \\
\text { creative. }\end{array}$ & \\
\hline
\end{tabular}

$\left({ }^{*} p<0.05\right)$ 
Table 4 Means scores of TQM practices in different cultural clusters

\begin{tabular}{|c|c|c|c|c|c|c|}
\hline \multirow[b]{2}{*}{ TQM practices } & \multirow[b]{2}{*}{$\begin{array}{l}\text { Overall } \\
\text { ranking }\end{array}$} & \multicolumn{4}{|c|}{ Emergent cultural clusters $^{\#}$} & \multirow[b]{2}{*}{$\begin{array}{c}F- \\
\text { value* }\end{array}$} \\
\hline & & $\begin{array}{l}\text { Hierar- } \\
\text { chy } \\
\text { driven }\end{array}$ & $\begin{array}{l}\text { Clan- } \\
\text { driven }\end{array}$ & $\begin{array}{l}\text { Strong } \\
\text { compre- } \\
\text { hensive }\end{array}$ & $\begin{array}{l}\text { Weak } \\
\text { compre- } \\
\text { hensive }\end{array}$ & \\
\hline Process management & $3.66(1)$ & $3.61(2)$ & $4.04(1)$ & $4.11(1)$ & $3.04(3)$ & 15.15 \\
\hline $\begin{array}{l}\text { Customer } \\
\text { management }\end{array}$ & $3.60(2)$ & $3.65(1)$ & $3.76(2)$ & $3.94(3)$ & $3.06(2)$ & 8.91 \\
\hline $\begin{array}{l}\text { Top management } \\
\text { leadership }\end{array}$ & $3.53(3)$ & $3.59(3)$ & $3.64(3)$ & $4.02(2)$ & $2.86(4)$ & 15.13 \\
\hline $\begin{array}{l}\text { Supplier } \\
\text { management }\end{array}$ & $3.48(4)$ & $3.38(4)$ & $3.48(5)$ & $3.92(4)$ & $3.12(1)$ & 8.76 \\
\hline People management & $3.31(5)$ & $3.27(5)$ & $3.49(4)$ & $3.78(5)$ & $2.76(5)$ & 11.53 \\
\hline $\begin{array}{l}\text { Continual } \\
\text { improvement }\end{array}$ & $3.26(6)$ & $3.22(6)$ & $3.41(6)$ & $3.69(6)$ & $2.77(7)$ & 8.58 \\
\hline $\begin{array}{l}\text { Organizational } \\
\text { learning }\end{array}$ & $3.24(7)$ & $3.20(7)$ & $3.31(7)$ & $3.69(6)$ & $2.75(6)$ & 9.71 \\
\hline $\begin{array}{l}\text { Quality information } \\
\text { management }\end{array}$ & $3.01(8)$ & $2.89(8)$ & $3.24(8)$ & $3.53(8)$ & $2.48(8)$ & 8.45 \\
\hline
\end{tabular}

( ${ }^{\#}$ Figures in parentheses represent the ranking of TQM practices for the respective cultural cluster; $* p<0.05$ ) 